\title{
Konsentrasi Logam Kadmium (Cd) dalam Jaringan Lunak Kerang Simping (Amusium pleuronectes) dan Sedimen di Perairan Teluk Semarang dan Hubungannya dengan Tingkat Kerja Osmotik
}

\author{
Concentration of Cadmium (Cd) in the Soft Tissue Scallop (Amusium pleuronectes) and Sediments in Semarang Bay \\ Waters and its Relationship with Osmotic Work Levels
}

\section{Eka Sugiarti, Haeruddin, Sutrisno Anggoro}

Program Studi Manajemen Sumberdaya Perairan, Departemen Sumberdaya Akuatik Fakultas Perikanan dan Ilmu Kelautan, Universitas Diponegoro

Jl. Prof. Soedarto, SH, Tembalang, Semarang, Jawa Tengah - 50275, Telp/Fax. +6224 7474698

Email : ekasugiarti26@gmail.com

\begin{abstract}
ABSTRAK
Perairan Teluk Semarang merupakan pantai utara Jawa yang terbentang dari Kabupaten Kendal hingga Kabupaten Demak. Perairan ini dekat pelabuhan Tanjung Mas dan pemukiman, berbagai macam industri, sehingga berpotensi tercemar berbagai jenis limbah. Salah satu jenis limbahnya adalah logam berat. Kerang Simping merupakan biota filter feeder dan sessile, sehingga logam berat di perairan akan terakumulasi pada sedimen dan tubuh kerang melalui rantai makanan. Osmoregulasi merupakan upaya hewan air mengontrol keseimbangan ion di dalam tubuh dan lingkungannya. Hal ini menjadi alasan penelitian dilaksanakan untuk mengetahui konsentrasi logam Cd pada kerang Simping dan sedimen di perairan Teluk Semarang dan hubungannya dengan tingkat kerja osmotik. Metode yang digunakan adalah metode deskriptif dan korelasi dengan penentuan lokasi sampling menggunakan metode purposive sampling. Penelitian dilakukan pada bulan Mei 2019. Hasil penelitian menunjukan konsentrasi logam Cd pada jaringan lunak kerang Simping di perairan Teluk Semarang adalah sebesar $<0,00001 \mathrm{mg} / \mathrm{kg}$. Hal ini menandakan bahwa logam Cd yang terkandung dalam kerang Simping sangat kecil sehingga tidak terdeteksi oleh alat. Logam Cd pada sedimen di perairan Teluk Semarang tiap stasiunnya memiliki nilai rata-rata sebesar: 82,2057; 58,4483; 68,0787 mg/kg. Hubungan logam Cd pada sedimen dengan osmolaritas hemolimfe kerang Simping menunjukkan hubungan hubungan linier bersifat positif dengan nilai $\mathrm{R}^{2}$ sebesar 0,259 yang artinya tingkat keeratan rendah. Hubungan logam Cd pada sedimen dan tingkat kerja osmotik memiliki hubungan linier yang bersifat negatif dengan nilai $\mathrm{R}^{2}$ sebesar 0,236 yang artinya tingkat keeratan rendah.
\end{abstract}

Kata Kunci: Kerang Simping; Logam Berat; Kadmium; Tingkat Kerja Osmotik

\begin{abstract}
The waters of Semarang Bay are the northern coast of Java which stretches from Kendal Regency to Demak Regency. These waters are near the port of Tanjung Mas and settlements, various industries, so that it is potentially polluted by various types of waste. One type of waste is heavy metal. The scallop is a biota filter feeder and sessile, so that heavy metals in the water will accumulate in the sediment and body of the shell through the food chain. Osmoregulation is an attempt by aquatic animals to control the balance of ions in the body and its environment. This is the reason the research was carried out to determine the concentration of $\mathrm{Cd}$ metal in scallops and sediments in the waters of Semarang Bay and their effect on the level of osmotic work. The method used is descriptive and correlation methods by determining the sampling location using purposive sampling method. The study was conducted in May 2019. The results showed the concentration of Cd in soft tissue of scallop shells in Semarang Bay waters was $<0.00001 \mathrm{mg} / \mathrm{kg}$. This indicates that the Cd metal contained in the scallop is so small that it is not detected by the tool. Cd metal in sediments in the waters of Semarang Bay each station has an average value : 82.2057; 58,4483; $68.0787 \mathrm{mg} / \mathrm{kg}$. The relationship of $C d$ metal in sediments with hemolymph osmolarity of scallops showed a positive linear relationship with an $R 2$ of 0.259, which means a low level of closeness. The relationship of Cd metal on sediment and osmotic work rate has a negative linear relationship with $R 2$ value of 0.236 , which means a low level of closeness.
\end{abstract}

Keywords: Scallop, Heavy Metal, Cadmium, Osmotic Work Level

${ }^{\odot}$ Copyright by Management of Aquatic Resources (MAQUARES) 


\section{PENDAhUluAN}

Nama ilmiah kerang simping adalah Amusium pleuronectes, merupakan salah satu jenis kerang yang memiliki nilai ekonomis cukup penting. Simping hidup di daerah sublitoral kedalaman antara 10-80 $\mathrm{m}$, dengan dasar perairan pasir lumpur. Terlepas dari kelebihannya, kerang ini dapat hidup di daerah yang bersih sampai tercemar. Jika kerang simping mendapatkan asupan makanan dari perairan yang tercemar, maka tubuhnya juga akan terpengaruh karena kerang merupakan filter feeder sehingga bahan pencemar dan logam berat dapat terakumulasi.

Osmoregulasi merupakan upaya hewan air untuk mengontrol keseimbangan antara ion di dalam tubuh dan lingkungannya melalui mekanisme pengaturan osmosisnya. Kelangsungan hidup organisme dipengaruhi oleh keseimbangan antara kandungan ion cairan tubuh dengan kandungan ion dari lingkungannya. Apabila gradien osmotik antara cairan tubuh dengan media lingkungannya terlalu tinggi, maka akan menyebabkan proses fisiologis terganggu, stress bahkan dapat menyebabkan kematian (mortalitas) (Porchase et al., 2009). Oleh karena itu penelitian ini diperlukan untuk mengetahui konsentrasi logam Cd dalam kerang simping (Amusium pleuronectes) dan sedimen di perairan Teluk Semarang dan hubungannya dengan tingkat kerja osmotik. Tujuan dalam penelitian ini adalah mengetahui konsentrasi logam berat Cd pada jaringan lunak kerang simping di perairan Teluk Semarang, mengetahui konsentrasi logam berat Cd pada sedimen di perairan Teluk Semarang, dan mengetahui keterkaitan kandungan logam berat $\mathrm{Cd}$ pada sedimen dengan osmolaritas hemolimfe dan tingkat kerja osmotik pada jaringan lunak kerang simping di perairan Teluk Semarang,

\section{MATERI DAN METODE PENELITIAN}

\section{Materi}

Penelitian dilakukan pada bulan Mei 2019 di perairan Teluk Semarang. Analisis logam berat di Laboratorium Teknik Lingkungan, Universitas Diponegoro Semarang dan pengukuran tingkat kerja osmotik (TKO) di Laboratorium Pengelolaan Sumberdaya Ikan dan Lingkungan, Departemen Sumberdaya Akuatik, Fakultas Perikanan dan Ilmu Kelautan Universitas Diponegoro.

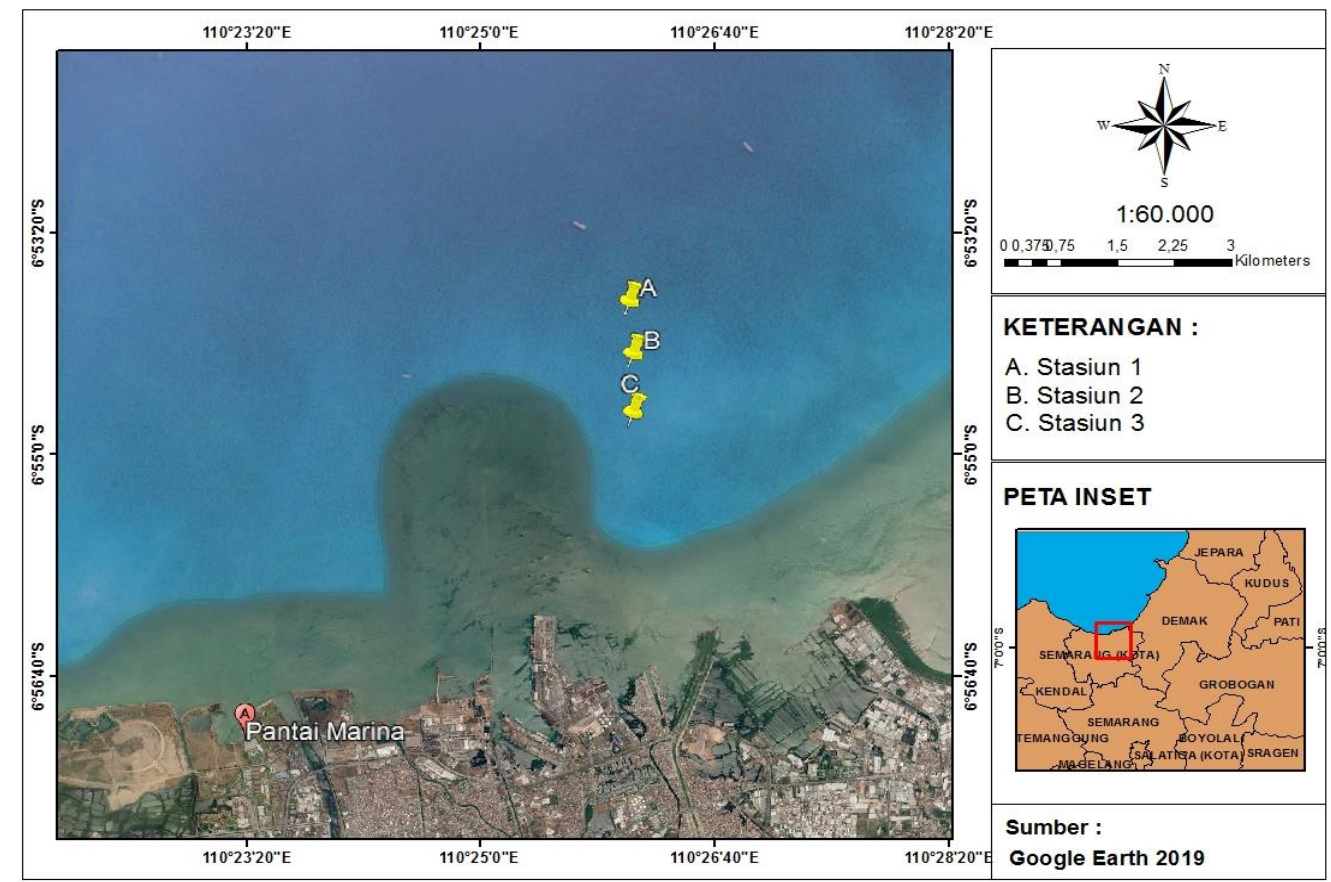

Alat yang digunakan dalam penelitian ini adalah perahu nelayan untuk transportasi menangkap kerang, automatic micro-osmometer roebling digunakan untuk mengukur osmolaritas air dan hemolimfe kerang simping, termometer digunakan untuk mengukur temperatur, salino refraktometer digunakan untuk mengukur salinitas, cool box digunakan untuk menyimpan sampel, botol PE digunakan untuk menyimpan sampel air, pH paper digunakan untuk mengukur $\mathrm{pH}$ air media, botol winkler digunakan untuk wadah sampel air dalam analisis oksigen terlarut. Bahan yang digunakan dalam penelitian ini adalah kerang simping, sedimen dan sampel air media dan reagen untuk analisis oksigen terlarut antara lain $\mathrm{MnSO}_{4}, \mathrm{H}_{2} \mathrm{SO}_{4}, \mathrm{NaOH}$ dalam $\mathrm{KI}, \mathrm{N}_{2} \mathrm{~S}_{2} \mathrm{O}_{3}$ dan amilum.

Metode

Metode yang digunakan adalah studi kasus, dengan analisis deskriptif dan korelasi. Studi kasus dengan analisis deskriptif mempelajari atau mengamati objek secara mendalam pada waktu, tempat dan populasi yang terbatas. Hasil dari pengamatan tersebut hanya berlaku secara lokal dan tidak berlaku pada tempat dan waktu yang berbeda. Studi kasus analisis deskriptif dalam penelitian ini adalah mengetahui konsentrasi logam kadmium (Cd) pada kerang 
simping dan sedimen serta tingkat kerja osmotik. Studi kasus analisis korelasi dilakukan untuk mengetahui pengaruh konsentrasi logam kadmium (Cd) dalam kerang simping dan sedimen terhadap tingkat kerja osmotik.

Penentuan lokasi sampling ditentukan dengan menggunakan metode "Purposive Sampling". Menurut Sugiyono (2012), purposive sampling adalah teknik penentuan sampel dengan pertimbangan tertentu. Pertimbangan pada pengambilan sampel ini adalah dipilih lokasi-lokasi yang merupakan tempat hidup kerang simping, berdasarkan informasi dari nelayan perairan Teluk Semarang. Pengambilan sampel kerang simping dilakukan pada 3 stasiun. Lokasi pengambilan sampel pada stasiun A yaitu S 06 54'00.6” E $110^{\circ} 26^{\prime} 16.0^{\prime \prime}$, stasiun B yaitu S 06 52'53.7' E $110^{\circ} 26^{\prime} 59.3^{\prime \prime}$ dan stasiun C yaitu S $06^{\circ} 54^{\prime} 54.4^{\prime \prime}$ E $110^{\circ} 26^{\prime} 29.9^{\prime \prime}$.

Pengambilan kerang simping (Amusium pleuronectes) menggunakan jaring arad nelayan yang langsung ke dasar perairan. Sampel kerang simping (Amusium pleuronectes) diambil pada lokasi menurut kebiasaan nelayan menangkap kerang kemudian dimasukkan ke dalam plastik klip dan disimpan di dalam cool box agar sampel kerang tetap segar. Pengambilan sampel kerang simping (Amusium pleuronectes) dan sedimen dilakukan setelah pengukuran kualitas air. Parameter kualitas air yang diukur adalah suhu, salinitas, DO, dan $\mathrm{pH}$. Analisa logam berat Cd dalam jaringan lunak kerang simping (Amusium pleuronectes) dan sedimen dilakukan dengan metode Atomic Absorption Spectrophotometer (ASS).

Nilai tingkat kerja osmotik kerang simping didapatkan dengan menggunakan automatic micro-osmoter roebling.Tingkat kerja osmotik didapatkan dengan mengukur osmolaritas media dan hemolimfe. Pengukuran pada osmolaritas hemolimfe, terlebih dahulu kerang simping diambil haemolymphnya sebanyak $0,01 \mathrm{ml}$ serta air medianya kemudian dimasukkan kedalam microtube. Haemolymph yang sudah terkumpul lalu dilakukan pengukuran dengan automatic micro-osmoter roebling. Nilai osmolaritas akan ditampilkan pada alat tersebut.

Analisis Data

Tingkat kerja osmotik (TKO) dihitung dari selisih nilai osmolaritas hemolimfe kerang simping dengan osmolaritas media. Perhitungan tingkat kerja osmotik menggunakan persamaan dari Anggoro dan Nakamura (2005), dengan rumus sebagai berikut :

$$
\mathrm{TKO}=[\mathrm{P} \text { osmo haemolymph }-\mathrm{P} \text { osmo media }]
$$

Keterangan :

TKO : tekanan osmotik (mOsm/ $\left./ \mathrm{H}_{2} \mathrm{O}\right)$

$\mathrm{P}$ osmo haemolymph : tekanan osmotik cairan tubuh $\left(\mathrm{mOsm} / \mathrm{I} \mathrm{H}_{2} \mathrm{O}\right)$

P osmo media : tekanan osmotik/ osmolaritas media (mOsm/ $/ \mathrm{H}_{2} \mathrm{O}$ )

Analisis regresi korelasi digunakan untuk mengetahui hubungan konsentrasi logam $\mathrm{Cd}$ pada sedimen dengan tingkat kerja osmotik. Alat bantu yang digunakan dalam melaksanakan uji statistik adalah program microsoft excel. Analisis regresi korelasi untuk menggambarkan garis yang menunjukan arah suatu hubungan antar variabel, dan juga digunakan untuk melakukan suatu prediksi. Analisa ini digunakan untuk menelaah hubungan antara dua variabel atau lebih, terutama menelusuri pola hubungan yang modelnya belum diketahui dengan sempurna. Adapun persamaan umum dari regresi menurut Sari (2014) adalah sebagai berikut :

$$
\mathrm{Y}=\mathrm{a}+\mathrm{b} \cdot \mathrm{X}
$$

Keterangan :

Y : variabel terikat

a : parameter intersept (garis potongan kurva terhadap sumbu Y)

$\mathrm{b}$ : koefisien regresi (kemiringan atau slope kurva linear)

$\mathrm{X}$ : variabel bebas

\section{HASIL DAN PEMBAHASAN}

\section{Pengukuran Parameter Lingkungan di Lokasi Penelitian}

Pengukuran parameter lingkungan dilakukan untuk kelengkapan data pendukung sebagai gambaran umum keadaan perairan Teluk Semarang. Pengukuran parameter tersebut dilakukan di setiap stasiun. Pengukuran pada stasiun A dilakukan pada pukul 09.17 WIB pada saat cuaca sedang cerah. Pengukuran pada stasiun B dilakukan pada pukul 10.33 WIB, sedangkan pengukuran pada stasiun C dilakukan pada pukul 11.33 WIB. Hasil pengukuran parameter lingkungan di perairan Teluk Semarang terdapat pada Tabel 1 sebagai berikut:

Tabel 1. Parameter Lingkungan pada Tiga Stasiun di Perairan Teluk Semarang

\begin{tabular}{lrrrrrrrrr}
\hline Parameter & \multicolumn{3}{c}{ Stasiun 1 } & \multicolumn{3}{c}{ Stasiun 2 } & \multicolumn{3}{c}{ Stasiun 3 } \\
\cline { 2 - 9 } Lingkungan & Titik 1 & Titik 2 & Titik 3 & Titik 1 & Titik 2 & Titik 3 & Titik 1 & Titik 2 & Titik 3 \\
\hline Salinitas $(\%$ ( $)$ & 30 & 31 & 30 & 28 & 30 & 30 & 30 & 30 & 30 \\
Suhu $\left({ }^{\circ} \mathrm{C}\right)$ & 31 & 31 & 31 & 29 & 29 & 29 & 29 & 29 & 29 \\
DO $(\mathrm{mg} / \mathrm{ll})$ & 4,8 & 5,2 & 5 & 3,6 & 4,8 & 4,2 & 4 & 4,6 & 5 \\
$\mathrm{Ph}$ & 7 & 7 & 7 & 7 & 7 & 7 & 7 & 7 & 7 \\
\hline
\end{tabular}

Konsentrasi Logam Kadmium (Cd) dalam Jaringan Lunak Kerang Simping (Amusium pleuronectes) pada Tabel 2.

Hasil uji logam berat kadmium dalam jaringan lunak kerang simping (Amusium pleuronectes) dapat dilihat 
Konsentrasi Logam Kadmium (Cd) dalam Jaringan Lunak Kerang Simping dan Sedimen di Teluk Semarang

Tabel 2. Konsentrasi Logam Kadmium (Cd) Dalam Jaringan Lunak Kerang Simping (Amusium pleuronectes) di Perairan Teluk Semarang

\begin{tabular}{|c|c|c|c|c|}
\hline \multirow{2}{*}{ Pengulangan } & \multicolumn{3}{|c|}{ Konsentrasi logam berat kadmium (Cd) (mg/kg) } & \multirow{2}{*}{ SNI 7387:2009 } \\
\hline & Stasiun A & Stasiun B & Stasiun C & \\
\hline 1 & $<0,00001$ & $<0,00001$ & $<0,00001$ & \\
\hline 2 & $<0,00001$ & $<0,00001$ & $<0,00001$ & $0,1(\mathrm{mg} / \mathrm{kg})$ \\
\hline 3 & $<0,00001$ & $<0,00001$ & $<0,00001$ & \\
\hline
\end{tabular}

Berdasarkan tabel diatas dapat diketahui bahwa konsentrasi logam kadmium (Cd) pada setiap stasiun dan disetiap pengulangan diperoleh hasil $<0,00001 \mathrm{mg} / \mathrm{kg}$. Hal ini menandakan bahwa logam berat Cd yang terkandung dalam kerang simping sangat kecil sehingga tidak terdeteksi oleh alat. Konsentrasi logam $\mathrm{Cd}$ pada ketiga stasiun tidak melebihi ambang batas yang ditetapkan menurut SNI 7387 tahun 2009 yaitu sebesar 0,1 mg/kg dan tidak melebihi standar baku mutu logam berat untuk biota konsumsi dari Surat Keputusan Direktorat Jenderal Pengawasan Obat dan Makanan, Departemen Kesehatan Republik Indonesia Nomor 03725/B/SK/1989 sebesar 1 ppm.

Tidak terdeteksinya kandungan logam berat $\mathrm{Cd}$ pada kerang simping (Amusium pleuronetes) disebabkan oleh beberapa faktor salah satunya adalah karena logam berat yang terserap oleh kerang simping memang sedikit, dan diduga logam Cd yang terkandung dalam air cukup kecil. Hal ini mungkin terjadi karena kerang simping merupakan biota filter feeder. Logam Cd yang terakumulasi pada sedimen bersifat anorganik, sedangkan $\mathrm{Cd}$ di tubuh kerang simping bersifat organik. Untuk mengubah anorganik menjadi organik butuh perantara yaitu partikel organik seperti plankton yang dimanfaatkan sebagai makanan kerang simping. Jadi apabila logam $\mathrm{Cd}$ pada air kecil maka pada kerang simping juga kecil karena kerang simping makan dengan cara menyaring partikel-partikel di dalam air. Hal ini diperkuat oleh Dharmaraj et al. (2004), seperti bivalvia pada umumnya, kerang simping merupakan hewan filter feeder dengan makanan utama plankton dan detritus organik.

Berdasarkan penelitian diketahui bahwa perairan Teluk Semarang berdekatan dengan pelabuhan Tanjung Mas yang di dalamnya terdapat berbagai macam aktivitas industri dan PLTU. Beberapa industri yang berdiri di sekitar pelabuhan Tanjung Mas adalah CV. Sumber Banu pabrik kertas, PT. Pohon Cemara pabrik keramik, dan PT. Kalimas. Menurut Hananingtyas (2017), Adanya pencemaran Cd di perairan Laut Utara Jawa Tengah dapat diakibatkan karena adanya pembuangan limbah yang tidak ramah lingkungan dari proses kegiatan industri industri yang berdiri di sekitar wilayah pantura Jawa Tengah. Menurut Yulianto et al. (2006), kandungan $\mathrm{Pb}$ di pantai utara Jawa Tengah pada kerang berkisar antara 0,008-18 mg/kg, kandungan $\mathrm{Cu} 0,5-186 \mathrm{mg} / \mathrm{kg}$, kandungan $\mathrm{Cd}$ berkisar $0,5-3 \mathrm{mg} / \mathrm{kg}$ dan untuk kandungan Cr berkisar antara 0,006-4 mg/kg. Berdasarkan data yang ada, menunjukan bahwa pantai utara Jawa Tengah telah terkontaminasi logam berat yang cukup besar.

\section{Konsentrasi Logam Kadmium (Cd) dalam Sedimen}

Hasil uji logam berat kadmium dalam sedimen di Perairan Teluk Semarang dapat dilihat pada Tabel 3.

Tabel 3. Konsentrasi Logam Berat Kadmium (Cd) Dalam Sedimen di Perairan Teluk Semarang

\begin{tabular}{lccr}
\hline \multirow{2}{*}{ Pengulangan } & \multicolumn{3}{c}{ Konsentrasi logam berat kadmium $(\mathrm{Cd})(\mathrm{mg} / \mathrm{kg})$} \\
\cline { 2 - 4 } & Stasiun A & Stasiun B & Stasiun C \\
\hline 1 & 94,0763 & 54,8305 & 68,1959 \\
2 & 77,7722 & 57,3583 & 63,6019 \\
3 & 74,7685 & 63,1560 & 72,4384 \\
\hline Rata - rata & 82,2057 & 58,4483 & 68,0787 \\
\hline
\end{tabular}

Berdasarkan tabel diatas dapat diketahui bahwa konsentrasi logam Cd pada sedimen di stasiun A memiliki rata-rata sebesar $82,2057 \mathrm{mg} / \mathrm{kg}$, pada stasiun B rata-ratanya sebesar $58,4483 \mathrm{mg} / \mathrm{kg}$, dan stasiun C sebesar 68,0787 $\mathrm{mg} / \mathrm{kg}$. Baku mutu logam berat pada lumpur atau sedimen di Indonesia belum ditetapkan, padahal senyawa-senyawa logam berat lebih banyak terakumulasi dalam sedimen karena adanya proses pengendapan. Berdasarkan baku mutu yang telah ditetapkan oleh Australian and New Zealand Environment and Conservation Council (ANZECC, 2000) adalah sebesar $1,5 \mathrm{mg} / \mathrm{kg}$, dan jika logam berat di sedimen dibandingkan dengan baku mutu yang ditetapkan oleh Norwegia IADC/CEDA (Norwegia) yaitu $(<0,25 \mathrm{mg} / \mathrm{kg})$, maka logam Cd yang ada pada sedimen sudah melebihi baku mutu.

Konsentrasi logam berat di lingkungan perairan meningkat dengan kedekatan perairan tersebut pada kawasan padat industri. Hal ini dipengaruhi oleh beberapa faktor seperti lama waktu akumulasi, faktor fisika, kimia, maupun biologi. Banyaknya konsentrasi logam berat disebabkan oleh akumulasi logam berat dalam jangka waktu yang lama dan terus menerus pada sedimen yang mempunyai sifat relatif menetap. Menurut Siregar dan Jhon (2010), sedimen merupakan tempat penimbunan segala pencemar yang terdapat pada kolom air. Melalui proses pengikatan dengan bahan tersuspensi, terkoagulasi dan mengendap (sinking) dan menjadi tertimbun pada sedimen dasar. Penimbunan ini terus terjadi selagi adanya input pencemar dari badan air dan terikat dengan bahan tersuspensi dan mengendap. 
Rata-rata kandungan logam berat terendah adalah pada stasiun B yaitu sebesar 58,4483 mg/kg. Rendahnya konsentrasi logam berat tersebut bukan berarti tidak berdampak negatif terhadap perairan, tapi lebih disebabkan oleh kemampuan perairan tersebut untuk mengencerkan bahan cemaran yang cukup tinggi (Rochayatun et al., 2006). Jenis substrat yang tedapat pada lokasi penelitian umumnya adalah berlumpur. Ukuran partikel ini sangat berpengaruh dengan daya akumulasi logam berat. Hal ini diperkuat oleh Sahara (2009) yang menyatakan bahwa partikel sedimen yang halus memliki luas permukaan yang lebih besar dengan kerapatan ion yang lebih stabil untuk mengikat logam berat daripada partikel sedimen yang lebih besar.

\section{Tingkat kerja osmotik (TKO) dan Pola Osmoregulasi}

Tingkat kerja osmotik adalah selisih dari tekanan osmotik dalam tubuh (haemolymph) biota dengan tekanan osmotik media hidup biota itu sendiri. Hasil tingkat kerja osmotik kerang simping dapat dilihat pada Tabel 4.

Tabel 4. Tingkat Kerja Osmotik (TKO) kerang simping yang diperoleh di Perairan Teluk Semarang

\begin{tabular}{|c|c|c|c|c|c|}
\hline $\begin{array}{c}\text { Kode } \\
\text { Sampel }\end{array}$ & $\begin{array}{c}\text { Salinitas } \\
\% \%\end{array}$ & $\begin{array}{r}\text { Osmo Haemolymph } \\
\left(\mathrm{mOsm} / \mathrm{I} \mathrm{H}_{2} \mathrm{O}\right)\end{array}$ & $\begin{array}{r}\text { Osmo Media } \\
\left(\mathrm{mOsm} / \mathrm{I} \mathrm{H}_{2} \mathrm{O}\right) \\
\end{array}$ & $\begin{array}{r}\text { TKO } \\
\left(\mathrm{mOsm} / \mathrm{I} \mathrm{H}_{2} \mathrm{O}\right) \\
\end{array}$ & $\begin{array}{c}\text { Pola } \\
\text { Osmoregulasi } \\
\end{array}$ \\
\hline \multirow[t]{5}{*}{ A1 } & 30 & 890,05 & 871,45 & 18,60 & Hiperosmotik \\
\hline & & 889,93 & 871,55 & 18,38 & Hiperosmotik \\
\hline & & 889,97 & 871,40 & 18,57 & Hiperosmotik \\
\hline & & 890,02 & 871,43 & 18,59 & Hiperosmotik \\
\hline & & 889,94 & 871,50 & 18,44 & Hiperosmotik \\
\hline \multirow[t]{5}{*}{$\mathrm{A} 2$} & 31 & 896,70 & 900,50 & 3,80 & Mendekati Isoosmotik \\
\hline & & 896,68 & 900,48 & 3,80 & Mendekati Isoosmotik \\
\hline & & 896,74 & 900,51 & 3,77 & Mendekati Isoosmotik \\
\hline & & 896,69 & 900,50 & 3,81 & Mendekati Isoosmotik \\
\hline & & 896,72 & 900,50 & 3,78 & Mendekati Isoosmotik \\
\hline \multirow[t]{5}{*}{ A3 } & 30 & 889,93 & 871,44 & 18,49 & Hiperosmotik \\
\hline & & 889,98 & 871,45 & 18,53 & Hiperosmotik \\
\hline & & 890,04 & 871,44 & 18,60 & Hiperosmotik \\
\hline & & 890,00 & 871,43 & 18,57 & Hiperosmotik \\
\hline & & 890,01 & 871,44 & 18,57 & Hiperosmotik \\
\hline \multirow[t]{5}{*}{ B1 } & 28 & 884,96 & 813,35 & 71,61 & Hiperosmotik \\
\hline & & 885,00 & 813,33 & 71,67 & Hiperosmotik \\
\hline & & 885,02 & 813,35 & 71,67 & Hiperosmotik \\
\hline & & 884,98 & 813,34 & 71,64 & Hiperosmotik \\
\hline & & 885,02 & 813,35 & 71,67 & Hiperosmotik \\
\hline \multirow[t]{5}{*}{ B2 } & 30 & 888,99 & 871,48 & 17,51 & Hiperosmotik \\
\hline & & 889,12 & 871,48 & 17,64 & Hiperosmotik \\
\hline & & 888,97 & 871,45 & 17,52 & Hiperosmotik \\
\hline & & 889,08 & 871,44 & 17,64 & Hiperosmotik \\
\hline & & 889,06 & 871,50 & 17,56 & Hiperosmotik \\
\hline \multirow[t]{5}{*}{ B3 } & 30 & 889,04 & 871,50 & 17,54 & Hiperosmotik \\
\hline & & 889,02 & 871,50 & 17,52 & Hiperosmotik \\
\hline & & 889,06 & 871,49 & 17,57 & Hiperosmotik \\
\hline & & 889,04 & 871,50 & 17,54 & Hiperosmotik \\
\hline & & 889,05 & 871,49 & 17,56 & Hiperosmotik \\
\hline \multirow[t]{5}{*}{$\mathrm{C} 1$} & 30 & 890,01 & 871,55 & 18,46 & Hiperosmotik \\
\hline & & 890,00 & 871,55 & 18,45 & Hiperosmotik \\
\hline & & 890,00 & 871,54 & 18,46 & Hiperosmotik \\
\hline & & 890,02 & 871,55 & 18,47 & Hiperosmotik \\
\hline & & 890,01 & 871,54 & 18,47 & Hiperosmotik \\
\hline
\end{tabular}

${ }^{\circledR}$ Copyright by Management of Aquatic Resources (MAQUARES) 


\begin{tabular}{ccccc}
\hline C2 30 & 889,98 & 871,52 & 18,46 & Hiperosmotik \\
& 889,97 & 871,50 & 18,47 & Hiperosmotik \\
& 889,98 & 871,51 & 18,47 & Hiperosmotik \\
& 889,98 & 871,50 & 18,48 & Hiperosmotik \\
& 889,97 & 871,52 & 18,45 & Hiperosmotik \\
\hline C3 & 889,99 & 871,49 & 18,50 & Hiperosmotik \\
& 890,01 & 871,49 & 18,52 & Hiperosmotik \\
& 890,00 & 871,50 & 18,50 & Hiperosmotik \\
& 890,00 & 871,49 & 18,51 & Hiperosmotik \\
& 889,98 & 871,50 & 18,48 & Hiperosmotik \\
\hline
\end{tabular}

Rata - rata pola osmoregulasi kerang simping adalah hiperosmotik kecuali kode sampel A2 dimana pola osmoregulasinya dalah mendekati isoosmotik. Pola osmoregulasi hiperosmotik karena osmolaritas haemolymphnya lebih tinggi (hipertonik) dibandingkan dengan osmolaritas air medianya (hipotonik). Hal ini diperkuat oleh Novian et al. (2013) yaitu regulasi hiperosmotik terjadi karena kondisi osmolaritas darah biota lebih tinggi dibandingkan dengan osmolaritas media hidupnya. Kondisi hiperosmotik dan hipoosmotik menyebabkan pembelanjaan energi sangat besar.

Tingkat kerja osmotik paling tinggi terdapat pada kode sampel B1 dimana hasilnya sebesar 71,65 mOsm/ $\mathrm{H}_{2} \mathrm{O}$ dimana osmolaritas hemolimfe kerang simping lebih tinggi dibandingkan dengan osmolaritas media. Besarnya nilai TKO karena rentang antara osmolaritas hemolimfe dengan osmolaritas media yang terpaut jauh sehingga proses osmoregulasi yang harus dilakukan biota untuk mneyeimbangkan tekanan osmotiknya semakin besar. Hal ini diperkuat oleh Muliani (2016) yang menyatakan bahwa tingkat kerja osmotik yang dialami biota air adalah selisih dari osmolaritas tubuh dengan osmolaritas media hidupnya, apabila selisih osmolaritasnya besar maka akan berakibat pada besarnya tingkat kerja osmotik yang dilakukan dalam proses osmoregulasinya.

Hubungan Logam Cd pada Sedimen dan Hemolimfe Kerang Simping

Grafik hubungan logam Cd pada sedimen dan hemolimfe kerang simping dapat dilihat pada Gambar 2.

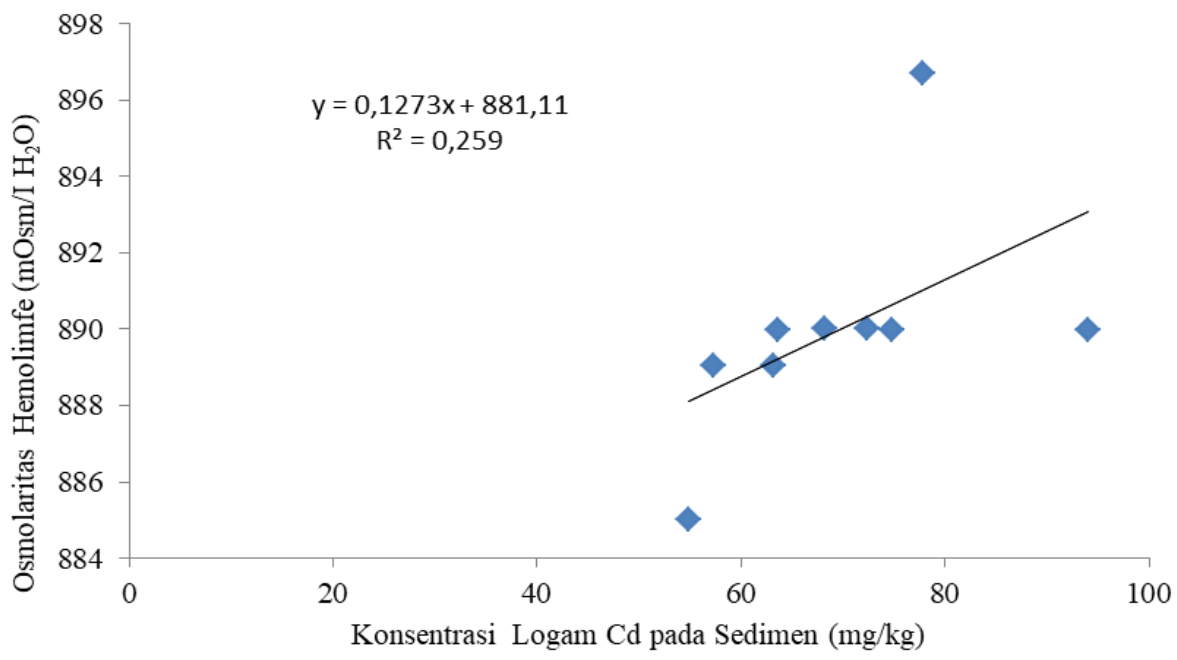

Berdasarkan gambar diatas, hasil analisis regresi menunjukan persamaan $\mathrm{y}=0,127 \mathrm{x}+881,1$ dengan nilai $\mathrm{R}^{2}=$ 0,259. Artinya $25,9 \%$ logam Cd pada sedimen mempengaruhi besarnya osmolaritas hemolimfe kerang simping dan $74,1 \%$ dipengaruhi oleh faktor lain. Hubungan logam Cd pada sedimen dengan osmolaritas hemolimfe kerang simping menunjukkan hubungan hubungan linier bersifat positif. Semakin tinggi kandungan logam $\mathrm{Cd}$ pada sedimen menyebabkan semakin tinggi pula nilai osmolaritas hemolimfe kerang simping. Menurut Kasril et al. (2017), apabila nilai determinasi semakin tinggi menandakan hubungan yang erat. Nilai logam $\mathrm{Cd}$ pada sedimen yang terendah yaitu sebesar $54,8305 \mathrm{mg} / \mathrm{kg}$ dan memiliki nilai osmolaritas hemolimfe sebesar 885,00 mOsm/ $/ \mathrm{H}_{2} \mathrm{O}$, nilai logam $\mathrm{Cd}$ pada sedimen sebesar $57,3583 \mathrm{mg} / \mathrm{kg}$ memiliki osmolaritas hemolimfe sebesar 889,04 mOsm/ $\mathrm{I} \mathrm{H}_{2} \mathrm{O}$.

Logam $\mathrm{Cd}$ yang ada pada sedimen akan mempengaruhi osmoregulasi kerang simping. Hal ini diperkuat oleh Sari et al. (2014), paparan zat beracun termasuk dapat merusak jaringan insang, sehingga hal ini dapat mengurangi konsumsi oksigen dan mengganggu fungsi osmoregulasi organisme air. Keadaan patologis insang yang semakin parah akibat paparan zat beracun dapat menyebabkan gangguan pernapasan dan akhirnya menyebabkan kematian organisme tersebut. 
Hasil pengukuran salinitas kode sampel A2 sebesar $31 \%$ nilai osmolaritas medianya adalah sebesar 900,50 mOsm/ $/ \mathrm{H}_{2} \mathrm{O}$, sedangkan salinitas pada kode sampel B1 yaitu $28 \%$ memiliki nilai osmolaritas medianya sebesar $813,34 \mathrm{mOsm} / \mathrm{I} \mathrm{H}_{2} \mathrm{O}$. Menurut Suharyanto dan Tjaronge (2009), salinitas berhubungan dengan tekanan osmotik air. Semakin tinggi salinitas akan semakin tinggi pula tekanan osmotik di lingkungannya.

\section{Hubungan Logam Cd pada Sedimen dan Tingkat Kerja Osmotik}

Grafik hubungan logam Cd pada sedimen dan tingkat kerja osmotik dapat dilihat pada Gambar 3.

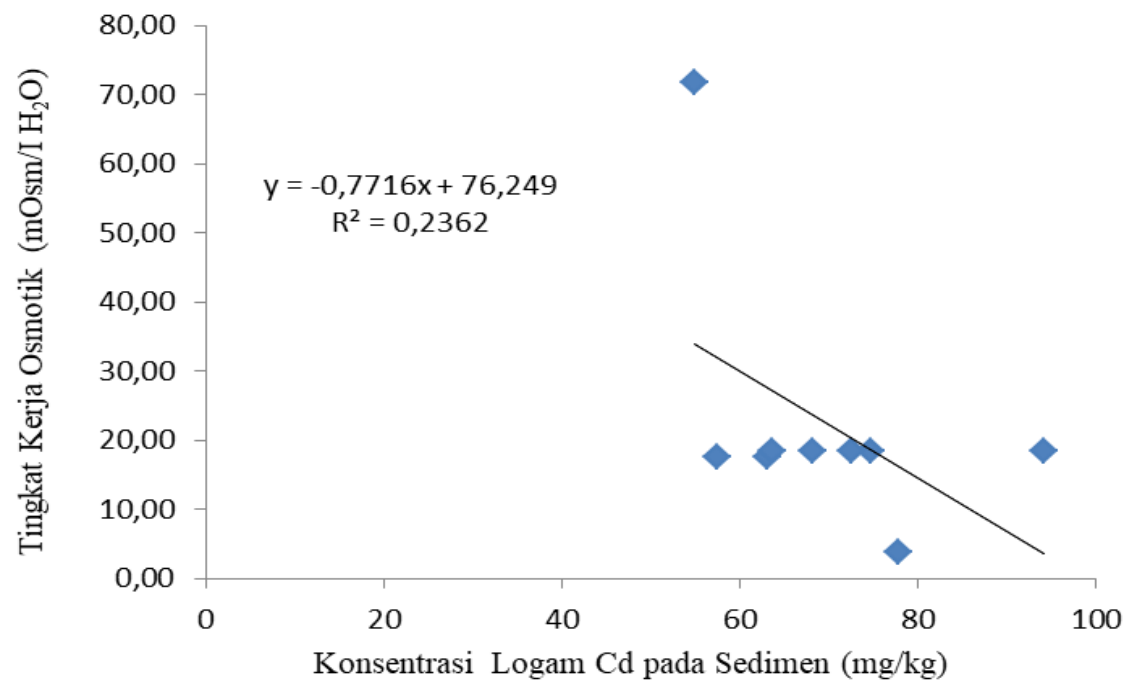

Bedasarkan gambar 3, hasil analisis regresi menunjukan persamaan $\mathrm{y}=-0,771 \mathrm{x}+76,24$ dengan nilai $\mathrm{R}^{2}=$ 0,236. Artinya 23,6 \% logam Cd pada sedimen mempengaruhi besarnya tingkat kerja osmotik dan 76,4\% dipengaruhi oleh faktor lain. Berdasarkan hasil analisis regresi di atas dapat diketahui bahwa logam Cd pada sedimen dan tingkat kerja osmotik memiliki hubungan linier yang bersifat negatif. Terlihat pada grafik, tingkat kerja osmotik kerang simping akan semakin menurun seiring dengan kenaikan logam Cd pada sedimen dan sebaliknya. Tingkat kerja osmotik terbesar yaitu 71,65 mOsm/ $/ \mathrm{H}_{2} \mathrm{O}$ yang terjadi saat nilai logam $\mathrm{Cd}$ pada sedimen sebesar 54,8305 mg/kg

$\mathrm{Cd}$ pada sedimen dapat mempengaruhi tingkat kerja osmotik kerang simping, namun pengaruhnya tidak terlalu besar. Cd yang ada pada sedimen dapat masuk ke tubuh biota dan apabila organ pada tubuh biota tersebut terpapar logam Cd dalam jangka waktu yang cukup lama, maka organ tersebut akan mengalami kerusakan. Menurut Wong (2000), terdapat beberapa pengaruh toksisitas logam pada ikan, terutama pengaruh toksisitas logam pada insang. Insang selain sebagai alat pernafasan juga digunakan sebagai alat pengaturan tekanan antara air dan dalam tubuh ikan (osmoregulasi). Insang merupakan organ pertama yang berhubungan langsung dengan bahan toksik di perairan, dengan permukaan yang luas dan terbuka, maka mengakibatkan bagian ini menjadi sasaran utama bagi bahan toksik yang ada di perairan.

Faktor lain yang dapat mempengaruhi tingkat kerja osmotik dan metabolisme biota kerang simping adalah seperti temperatur dan salinitas. Hal ini diperkuat oleh Lucas (2002) yang menyatakan bahwa faktor yang berpengaruh terhadap aktivitas metabolisme adalah faktor internal dan eksternal. Faktor internal yaitu hormon, parasit, infeksi penyakit, agen stress, dan status fisiologi dari hewan terkait dengan genetik, umur, reproduksi, dan sebagainya. Faktor eksternal yang penting antara lain pakan (untuk semua hewan), suhu, konsentrasi oksigen, salinitas, dan turbiditas.

\section{KESIMPULAN}

Berdasarkan penelitian yang telah dilakukan mengenai konsentrasi logam kadmium (Cd) dalam kerang simping (Amusium pleuronectes) dan sedimen di perairan Teluk Semarang dan hubungannya dengan tingkat kerja osmotik, dapat diperoleh kesimpulan sebagai berikut:

1. Konsentrasi logam berat $\mathrm{Cd}$ pada jaringan lunak kerang simping di perairan Teluk Semarang adalah sebesar $<$ $0,00001 \mathrm{mg} / \mathrm{kg}$.

2. Konsentrasi logam berat $\mathrm{Cd}$ pada sedimen di perairan Teluk Semarang adalah pada stasiun A memiliki rata-rata sebesar 82,2057 mg/kg, pada stasiun B rata-ratanya sebesar 58,4483 mg/kg, dan stasiun C sebesar $68,0787 \mathrm{mg} / \mathrm{kg}$.

3. Hubungan logam $\mathrm{Cd}$ pada sedimen dengan osmolaritas hemolimfe kerang simping menunjukkan hubungan hubungan linier bersifat positif dengan tingkat keeratan rendah. Hubungan logam Cd pada sedimen dan tingkat kerja osmotik memiliki hubungan linier yang bersifat negatif dengan tingkat keeratan rendah. 


\section{DAFTAR PUSTAKA}

Anggoro, S dan Nakamura, K. 2005. Osmotic Response and Feeding Pattern of Kuruma Shrimp (Penaeus japonicus) at Various Molting Stages. Research Report. Lab. of Propagation Physiology. Scientific article 11. Fisheries Fac. Kagoshima University, Kagoshima

Australian and New Zealand Environment and Conservatien Council (ANZECC), 2000. ANZECC interim sediment quality guidlines. Report for the environmental research institute of the supervising scientist. Sydney, Australia.

Dharmaraj, S., K. Shanmugasundaraman dan C. P. Suja. 2004. Larva Rearing and Spat Production of The Windowpane Shell Placuna placenta. Aquaculture Asia. April-June 2004. 20-28p

Ditjen POM. (1989). Batas Maksimum Cemaran Logam dalam Makanan. Lampiran Surat Keputusan Direktur Jendral Pengawasan Obat dan Makanan Nomor 03725/B/SK/VII/89. Halaman: 57.

Hananingtyas, I. 2017. Studi Pencemaran Kandungan Logam Berat Timbal (Pb) dan Kadmium (Cd) pada Ikan Tongkol (Euthynnussp) di Pantai Utara Jawa. Biotropic The Journal of Tropical Biology. 1 (2): 41-50.

IADC/CEDA. 1997. Environmental aspects of dredging-conventions, codes and conditions:marinedisposal. Internationa Association of Dredging Companies (IADC) \& Central Dredging Association, Netherland.

Kasril., Irma, D dan Nurfadillah. 2017. Hubungan Lebar Karapas dan Berat Kepiting Bakau (Scylla serrata) serta Faktor Kondisi di Perairan Aceh Singkil. Jurnal Ilmiah Mahasiswa Kelautan dan Perikanan Unsiyah. 2(3):444-453

Lucas, A. 2002. Bioenergetic of Aquatic Animals. Taylor \& Francis e-Library, 169 pp.

Muliani. 2016. Respon Fisiologis Ikan Patin Siam (Pangiasanodon hypothalamus) pada Berbagai Tingkat Kalsium Media. Berkala Perikanan Terubuk. 44(2):14-21

Novian, D.S., Diana, R, dan Sutrisno, A. 2013. Kebiasaan Makanan dan Osmoregulasi sebagai Landasan Domestikasi Keong Macan (Babylonia spirata I). Journal of Management of Aquatic Resources.2(2):249-257

Porchase, MM., Luis, R., Martines, C., and Ramos, R. 2009. Cortisol and Glucose Reliable indicator of Fish. American Journal of Aquatic Sciences, 4(2): 157-178

Rochayatun,E., Kaisupy,M.T., Rozak,A.2006. Distribusi Logam Berat dalam Air dan Sedimen di Perairan Muara Sungai Cisadane. Jurnal Makara Sains.10(1), 35-40

Sahara, E. 2009. Distribusi $\mathrm{Pb}$ dan $\mathrm{Cu}$ pada berbagai ukuran partikel Sedimen di Pelabuhan Benoa. Bali. JURNAL KIMIA 3 (2), JULI 2009 : 75-80.

Sari, A. 2014. Analisis Hubungan Panjang Berat Ikan Himmen (Glossogobius sp) di Danau Sentani Kabupaten Jayapura. The Journal of Fisheries Development. (1) :1-6

Siregar, Y.I dan Jhon E. 2010. Faktor konsentrasi Pb, Cd, Cu, Ni, Zn dalam sedimen perairan pesisir Kota Dumai. Maspari Journal $01: 1-10$

Sugiyono. 2012.Metode Penelitian Bisnis. Alfabeta, Bandung, 540 hlm

Suharyanto, dan M. Tjaronge. 2009. Pertumbuhan dan Sintasan Krablet Rajungan (Portunus pelagicus) pada Salinitas yang Berbeda. Jurnal Ichtyos. 8(1):7-12

Wong CK, Wong MH. 2000. Morphological and biochemical changes in the gills of tilapia (Oreochromis mossambicus) to ambient cadmium exposure. Aquatic Toxicology. 48: 517-527.

Yulianto, B., D. Suwarno., K. Amri., S. Oetari., A. Ridho., B. Widianarko. 2006. Penelitian Tingkat Pencemaran Logam Berat Di Pantai Utara Jawa Tengah. Badan Penelitian dan Pengembangan Jawa Tengah, 138 hlm. 